\title{
Hernia de acceso de laparoscopia
}

\author{
Fariña-Pérez LA.
}

Servicio de Urología. Hospital Povisa. Vigo.

Actas Urol Esp. 2008;32(7):769

$\mathrm{M}$ ujer de 70 años, con un peso de $92 \mathrm{k}$, y un índice de masa corporal de 35 , a quien se le practicó una nefrectomía parcial laparoscópica derecha por un carcinoma renal de $1,8 \mathrm{~cm}$, cerrando los puertos de acceso de $10 \mathrm{~mm}$ con la aguja de Reverdin ${ }^{1}$ (Fig. 1: TAC realizado en el postoperatorio temprano, la flecha señala el trayecto del acceso inferior, en la fosa ilíaca derecha). Sin embargo, presentó una hernia poco sintomática, no complicada, en este acceso inferior, (Figs. 2 y 3: TAC al año de la intervención, se muestran dos cortes consecutivos), que después de cuatro años de seguimiento no ha necesitado ser tratada.

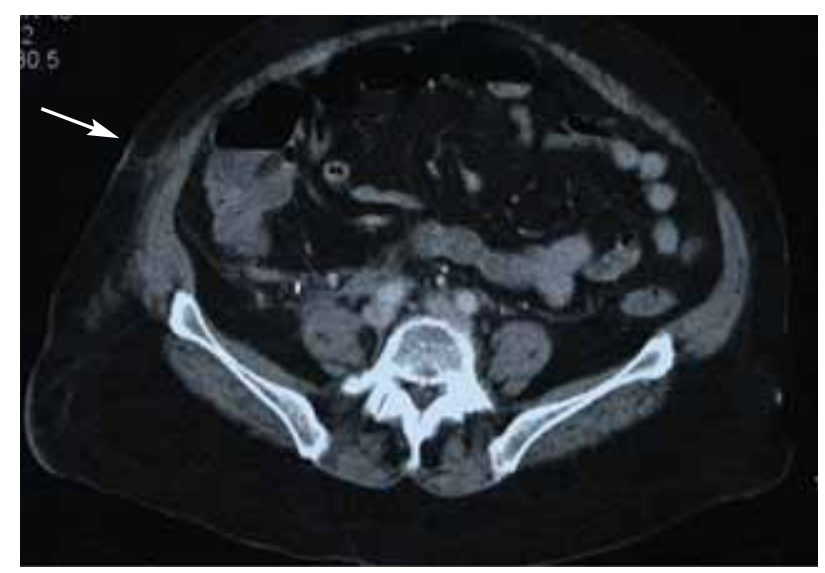

FIGURAS 1

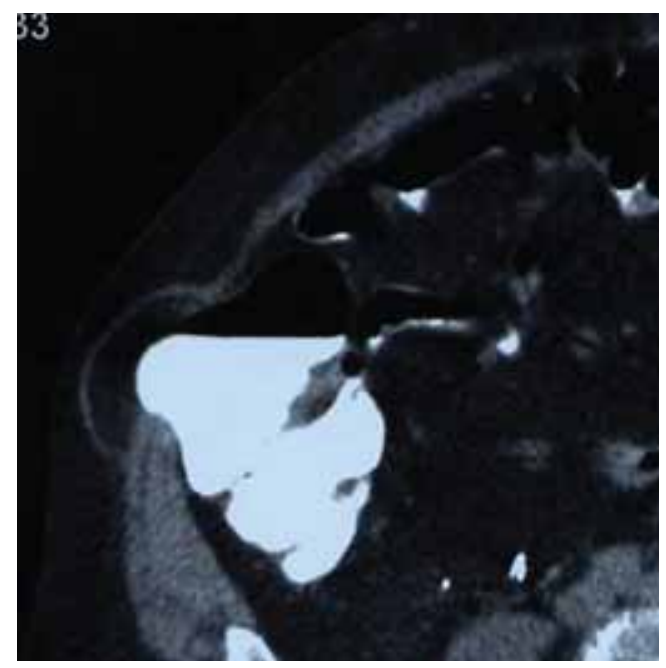

Una hernia en los accesos de laparoscopia se cree que ocurre entre un 2 por cien y un dos por mil procedimientos, aunque posiblemente la incidencia está infraestimada, pues se han visto hernias en accesos de 3 y $5 \mathrm{~mm}^{2}$, y muchas veces son asintomáticas. Preventivamente, se recomienda que todos los accesos de 10 o más mm sean cerrados, incluyendo si es posible el peritoneo y el plano músculofascial $^{3}$.

\section{REFERENCIAS}

1. Fariña LA, Zungri E. Cierre de los accesos laparoscópicos con aguja de Reverdin: un uso nuevo para un viejo instrumento. Actas Urol Esp. 2003 ;27:168-169.

2. Yee DS, Duel BP. Omental herniation through a 3-mm umbilical trocar site. J Endourol. 2006 ;20:133-134.

3. Pemberton RJ, Tolley DA, van Velthoven RF. Prevention and management of complications in urological laparoscopic port site placement. Eur Urol. 2006;50:958-968.

Correspondencia: Dr L.A. Fariña Pérez Servicio de Urología. Hospital POVISA

Salamanca 5. 36211 - Vigo (Pontevedra). Tel.: 986413144

E-mail autor: luisfarina@yahoo.com

Información artículo: Imágenes en Urología

Trabajo recibido: febrero 2007

Trabajo aceptado: marzo 2007

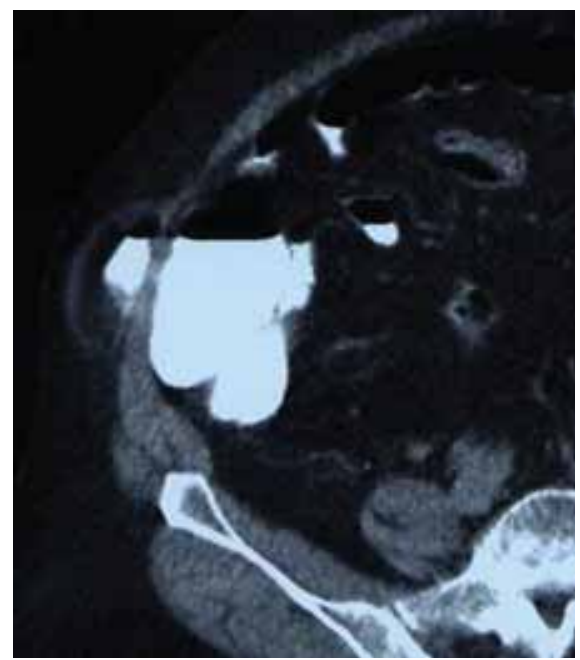

